\title{
The effect of scale in quantifying fire impacts on species habitats
}

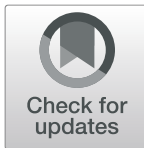

Ho Yi Wan ${ }^{1 *}$ D, Samuel A. Cushman² and Joseph L. Ganey ${ }^{2}$

\begin{abstract}
Background: Fire size and severity have increased in the western United States in recent decades, and are expected to continue to increase with warming climate. Habitats for many species are threatened by large and high-severity fires, but the effect of spatial scale on the relationship between fires and habitat modifications is poorly understood. We used the 2011 Wallow Fire - the largest wildfire in the state history of Arizona, USA — as a case study and assessed changes in predicted nesting habitat of the threatened Mexican spotted owl (Strix occidentalis Xántus de Vésey) in the first three years following the fire. Our objective was to explore potential relationships between burn severity and changes in habitat suitability at different spatial scales. To accomplish this, we applied a multi-scale optimized habitat selection model to pre- and post-fire landscapes and compared the differences in predictions along a continuous scale gradient.

Results: Fire effects on habitat quality were spatially variable and the strength and direction of relationships were scale-dependent. Spatial patterns of burn-severity mosaic resembled the patterns of habitat suitability change. High burn severity reduced nesting habitat suitability and this relationship was strongest at broad scales. Prefire habitat suitability was positively related to burn severity, again at fairly broad scales, but the relationship was weak. Low-severity fires had little effect on habitat suitability.
\end{abstract}

Conclusions: Multi-scale analysis may influence the statistical measures of goodness of fit in assessing fire effects on species and their habitats. Future studies should explicitly address spatial scale when quantifying fire effects.

Keywords: biodiversity, burn severity, fire severity, fragmentation, habitat loss, megafire, multi-scale, scaling, spotted owl

\section{Resumen}

Antecedentes: El tamaño y la severidad de los incendios se han incrementado en el oeste de los Estados Unidos en décadas recientes, y se espera que continuarán en aumento con el calentamiento climático global. Los hábitats para muchas especies están siendo amenazados por incendios grandes y de muy alta severidad, aunque sus efectos a escala espacial en la relación entre estos incendios y las modificaciones del hábitat son muy poco comprendidos. Usamos el incendio de Wallow, ocurrido en 2011 —el más grande en la historia del estado de Arizona, EEUU—como un estudio de caso y determinamos los cambios pronosticados en el hábitat de anidamiento del búho manchado (Strix occidentalis Xántus de Vésey) durante los tres años posteriores a este incendio. Nuestro objetivo fue explorar relaciones potenciales entre la severidad de los incendios y los cambios en la disponibilidad de hábitats a distintas escalas. Para lograr ese objetivo, aplicamos un modelo optimizado de selección de hábitats de escalas múltiples a paisajes previos y posteriores al paso del fuego y comparamos las diferencias en las predicciones a lo largo de un gradiente de escala continua.

(Continued on next page)

\footnotetext{
* Correspondence: hoyiwan@gmail.com

${ }^{1}$ School of Public and Community Health Sciences, University of Montana, 32

Campus Drive, Missoula, Montana, USA

Full list of author information is available at the end of the article
}

\section{Springer Open}

(c) The Author(s). 2020 Open Access This article is licensed under a Creative Commons Attribution 4.0 International License, which permits use, sharing, adaptation, distribution and reproduction in any medium or format, as long as you give appropriate credit to the original author(s) and the source, provide a link to the Creative Commons licence, and indicate if changes were made. The images or other third party material in this article are included in the article's Creative Commons licence, unless indicated otherwise in a credit line to the material. If material is not included in the article's Creative Commons licence and your intended use is not permitted by statutory regulation or exceeds the permitted use, you will need to obtain permission directly from the copyright holder. To view a copy of this licence, visit http://creativecommons.org/licenses/by/4.0/. 
(Continued from previous page)

Resultados: Los efectos del fuego en la calidad del hábitat fueron espacialmente variables y la fortaleza y dirección de las relaciones fueron escala-dependiente. Los patrones espaciales de los mosaicos de severidad del fuego se parecieron a los patrones de adecuación a los cambios de hábitat. Patrones de alta severidad redujeron la posibilidad de disponer de hábitats para anidamiento y esta relación se hizo más fuerte a escalas mayores. La disponibilidad de hábitats para anidamiento previo al fuego se relacionó positivamente con la severidad del incendio, nuevamente a escalas relativamente grandes, aunque la relación fue débil. Los fuegos de baja severidad tuvieron un efecto pequeño en la disponibilidad de hábitats.

Conclusiones: Los análisis multi-escala pueden influenciar las medidas estadísticas de bondad de ajuste para determinar los efectos del fuego sobre especies y sus hábitats. Futuros estudios deberán abordar explícitamente la escala espacial cuando se pretendan cuantificar los efectos del fuego.

\section{Introduction}

Historically, fire was the most dominant disturbance factor in forests across the western United States, and strongly influenced forest structure, composition, and ecological function (e.g., Agee 1993). Thus, fire is a natural and important component of these forest systems. The nature of wildfires may be changing in these systems, however, as a result of climate change, past management, and other anthropogenic causes. For example, many authors argue that forest wildfires have increased in size and severity in the western United States (Littell et al. 2009; Miller et al. 2009b; Dillon et al. 2011; Miller and Safford 2012; Williams 2013; Keyser and Westerling 2017; Reilly et al. 2017; Singleton et al. 2019) over the past several decades, especially in drier forest types. This conclusion is not universally accepted, however, with others arguing that fire size and severity have not diverged from historical norms (Odion and Hanson 2006; Williams and Baker 2012; Baker 2015a, 2015b; Doerr and Santin 2016; Hanson and Odion 2016).

Despite this debate, there is considerable evidence supporting the contention that fire size and severity have increased at least in recent decades. For example, the largest documented wildfires (often referred to as megafires; Attiwill and Binkley 2013, Williams 2013, Stephens et al. 2014) occurred after the turn of the millennium in many western states. These include the 2002 Hayman Fire in Colorado (56 000 ha; US Department of Agriculture 2004), the 2007 Milford Flat Fire in Utah (147 000 ha; Earth Observatory 2007), the 2011 Wallow Fire in Arizona (218 000 ha; US Department of Agriculture 2014), the 2012 Whitewater-Baldy Complex Fire in New Mexico (117 000 ha; US Department of Agriculture 2012), and the 2017 Thomas Fire in California (114 000 ha; Cal Fire 2018). This trend toward larger and more severe fires likely will carry into the near future because of influences from projected warmer and drier climate (McKenzie et al. 2004; Westerling et al. 2006; Littell et al. 2009, 2018; Flannigan et al. 2013; Barbero et al. 2015; Flatley and Fulé 2016; Kitzberger et al. 2017), changes in vegetation composition that favor fire (e.g., Balch et al. 2013), and increased probability of human-caused ignition as human populations increase (Balch et al. 2017; Schoennagel et al. 2017).

Increases in fire size and severity have led to concerns over the effects of fire in general, and of megafires in particular, on populations and habitats of native wildlife species, including the spotted owl (Strix occidentalis Xántus de Vésey; e.g., Jones et al. 2016; Ganey et al. 2017; Wan et al. 2018b; Wan et al. 2019b). There are three recognized subspecies of spotted owls-California (S. occidentalis occidentalis Xántus de Vésey), Mexican (S. occidentalis lucida Nelson), and northern (S. occidentalis caurina Merriam)in North America. Both the northern and Mexican subspecies are listed as threatened under the Endangered Species Act of 1973 (US Department of Interior 2012), while the California spotted owl is considered a species of conservation concern (Stine and Manley 2017). Throughout much of their range, all three subspecies of spotted owl nest selectively in late seral forests (US Department of Interior 2012; Gutiérrez et al. 2017) characterized by large, old trees and high canopy cover. Forest patches with these structural features are relatively rare on the landscape, and take centuries to develop. Fire, particularly high-severity fire, can quickly return these patches to early seral stages that do not function as nesting habitat (US Department of Interior 2012; Keane 2017). Consequently, increases in fire size and severity may lead to cumulative loss of spotted owl nesting habitat with long-term detrimental effects on owl populations (Jones et al. 2016; Stephens et al. 2016; Ganey et al. 2017).

The ecological effects of fire on spotted owls are poorly understood, however. Although a number of studies have examined responses of spotted owls to fire (see reviews in Bond 2016; Ganey et al. 2017; Lee 2018), results have not been consistent across these studies (Ganey et al. 2017; Wan et al. 2018b). Differences among studies may be related to many factors, including differences in size, severity, and spatial pattern among fires, forest types and consequent historical fire regimes, and owl subspecies. The relative importance of these factors remains unclear, however (Ganey et al. 2017; Wan et al. 2018b). 
Spatial scale is another potential factor that could explain differences among studies. It is well known that ecological relationships and observable patterns vary across spatial scales (e.g., Wiens 1989; Levin 1992; Chave 2013). Analysis conducted at inappropriate scales can lead to weak or incorrect inferences regarding the relationships between species responses and the environment (Thompson and McGarigal 2002; Shirk et al. 2014; Wan et al. 2017). Yet ecological studies that do not address the effect of scale remain ubiquitous, and those that claim to have investigated multiple scales typically select scales without thorough analysis (Wheatley and Johnson 2009; Jackson and Fahrig 2015; McGarigal et al. 2016). To quantitatively determine the appropriate scale of effect, the common approach (known as scale optimization) is to quantify environmental variables at a wide range of scales and then identify the one scale that yields the strongest species-environment relationship (Levin 1992; Jackson and Fahrig 2015). We are not aware of any studies that have used a scale optimization approach to quantify relationships between fire and species habitat. Fire is an integral component of many terrestrial ecosystems, and misdiagnosing the true nature of fire effects due to inappropriate choice of scales can have profound consequences in management. Therefore, the lack of scaling studies to understand fire effects on species habitat is somewhat concerning.

In this study, we examined the effect of spatial scale on changes in predicted nesting habitat of the Mexican spotted owl in the first three years after the 2011 Wallow Fire, the largest wildfire in the history of Arizona. Relatively few studies of relationships between spotted owls and fire have focused on this subspecies (Ganey et al. 2017; Wan et al. 2018b), and no studies of Mexican spotted owls have evaluated explicitly the effect of spatial scale on the relationship between fire and habitat change. We applied a validated, multi-scale, optimized habitat model to pre- and post-fire landscapes, evaluated the spatial patterns of burn severity, and evaluated changes in the predicted suitability of Mexican spotted owl habitat at different spatial scales. We also evaluated relationships between pre-fire predicted habitat suitability and burn severity at various spatial scales. In the absence of direct data on owl demographic response to this large fire, our results provide insight into changes in predicted habitat suitability, relationships between pre-fire suitability and fire severity, and the effects of spatial scale on interpretation of both parameters. This information should prove useful to managers interested in understanding and mitigating the effects of large wildfires on Mexican spotted owls.

\section{Methods}

\section{Study area}

Our study area covered the entire burned area of the Wallow Fire (latitude $33.6^{\circ} \mathrm{N}$, longitude $109.4^{\circ} \mathrm{W}$ ), located between the White Mountains of Arizona and the San Francisco Mountains of New Mexico, USA (Fig. 1). This fire was accidentally human-ignited in late spring of 2011. Fed by high winds and dry fuels, it burned for approximately 6 weeks (29 May to 8 July) and affected over 218000 ha of land. The fire created a complex mosaic of burn severity across the post-fire landscape (Fig. 2; Waltz et al. 2014). Importantly for our study of fire effects, salvage logging following the fire was minimal, affecting $<3 \%$ of the fire area (Fig. 2a; US Department of Agriculture 2019). Elevation ranged from 2400 to $2800 \mathrm{~m}$ within the fire perimeter. The primary vegetation types within the study area were ponderosa pine (Pinus ponderosa Dougl. ex Laws) and mixed-conifer forest, with the latter type dominated by mixtures of Douglas-fir (Pseudotsuga menziesii [Mirb.] Franco), white fir (Abies concolor Lindl. ex Hildebr.), and ponderosa pine. Southwestern white pine (Pinus strobiformus Engelm.), blue spruce (Picea pungens Engelm.), Engelmann spruce (Picea engelmannii Parry ex Engelm.), quaking aspen (Populus tremuloides Michx.), Gambel oak (Quercus gambelii Nutt.), and alligator juniper (Juniperus deppeana Steud.) were also common in the region. Postfire mortality of large trees $(\geq 37.5 \mathrm{~cm}$ diameter at breast height [dbh] for conifers and $\geq 20 \mathrm{~cm}$ dbh for aspen and oaks) was estimated at $\sim 50 \%$, with aspen and spruce having the highest estimated mortality (70 to $100 \%$; Waltz et al. 2014). Mortality of ponderosa pine, white fir, and Douglasfir were estimated at $42 \%, 57 \%$, and $55 \%$, respectively.

The study area is considered ecologically important to the Mexican spotted owl, and covers much of the Upper Gila Mountain Ecological Management Unit (EMU), one of five geographic EMUs recognized within the US range of the Mexican spotted owl (US Department of Interior 2012). This EMU contains the largest contiguous area of Mexican spotted owl habitat, supports the largest known regional population of Mexican spotted owls (Ganey et al. 2011), and previous studies suggest that the White Mountains region, located adjacent to the west side of the burned area, provides important core areas of connectivity and gene flow for the Mexican spotted owl (Wan 2018; Wan et al. 2018a, 2019a). There were 76 Protected Activity Centers (PACs; protected areas with a minimum size of 243 ha designated in areas occupied by resident Mexican spotted owls; US Department of Interior 2012) within the perimeter of the Wallow Fire prior to the burn (US Department of Interior 2012), although it is unknown how many of these PACs were occupied immediately prior to the fire.

\section{Fire data}

We obtained burn severity and fire perimeter data for the Wallow Fire from the Monitoring Trends in Burn Severity (MTBS) database (US Geological Survey 2017). MTBS offers several products that depict burn severity, including 


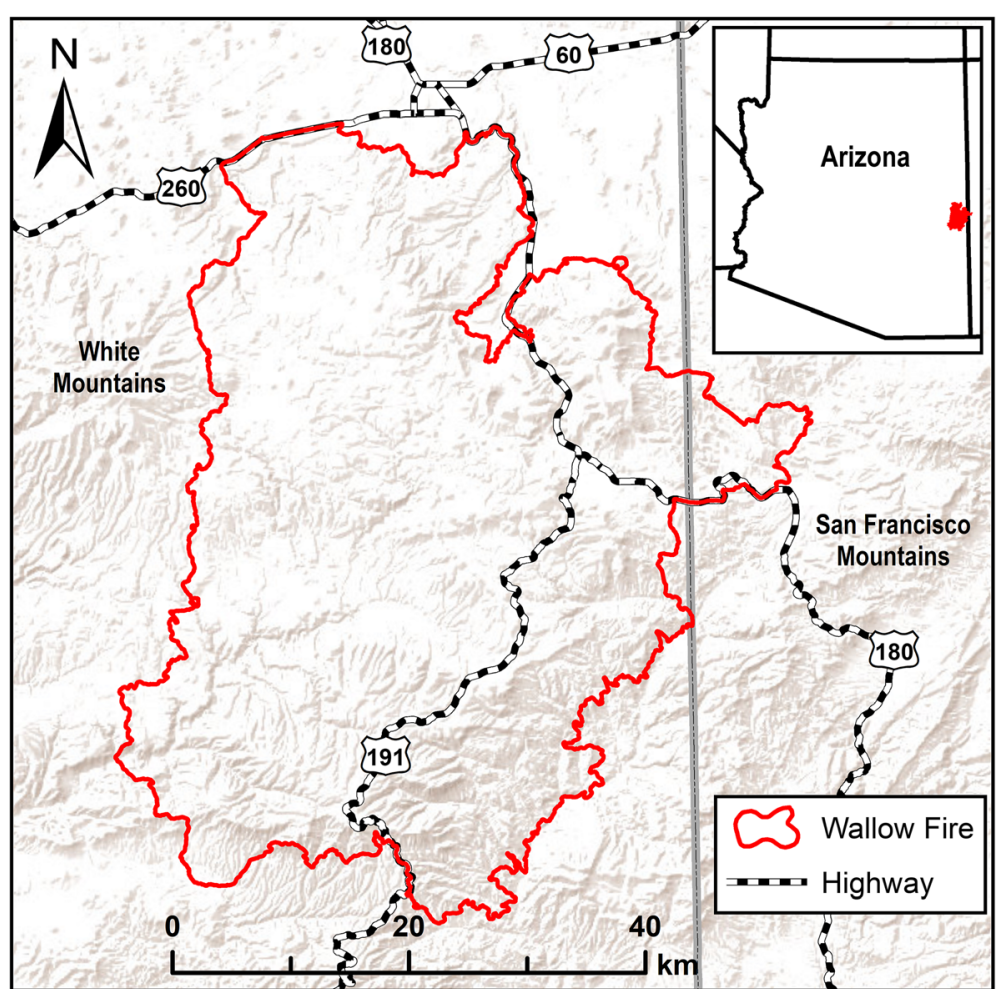

Fig. 1 Shaded relief map of the study area within Arizona, USA. The red line indicates the burn perimeter of the 2011 Wallow Fire, which burned over 218000 ha of land and was the largest documented wildfire in the history of Arizona

the differenced normalized burn ratio (dNBR), its relativized version (RdNBR), and a categorical burn severity map. The dNBR and RdNBR quantify burn severity as a continuous gradient, for which positive values indicate higher burn severity and a decrease in vegetation cover, and negative values indicate lower burn severity and an increase in vegetation cover (Miller et al. 2009a). In contrast, the categorical fire-severity map classifies area within the fire perimeter into one of four classes: unburned, low, moderate, and high burn severity (Eidenshink et al. 2007). Previous studies showed little to no difference between dNBR and RdNBR in terms of accuracy (Soverel et al. 2010; Cansler and McKenzie 2012).

We used the categorical burn-severity map to summarize pre- and post-fire conditions of habitat suitability relative to burn-severity class. In this study, habitat suitability was defined as the likelihood of a spotted owl selecting an area for nesting and was based on our habitat model predictions.
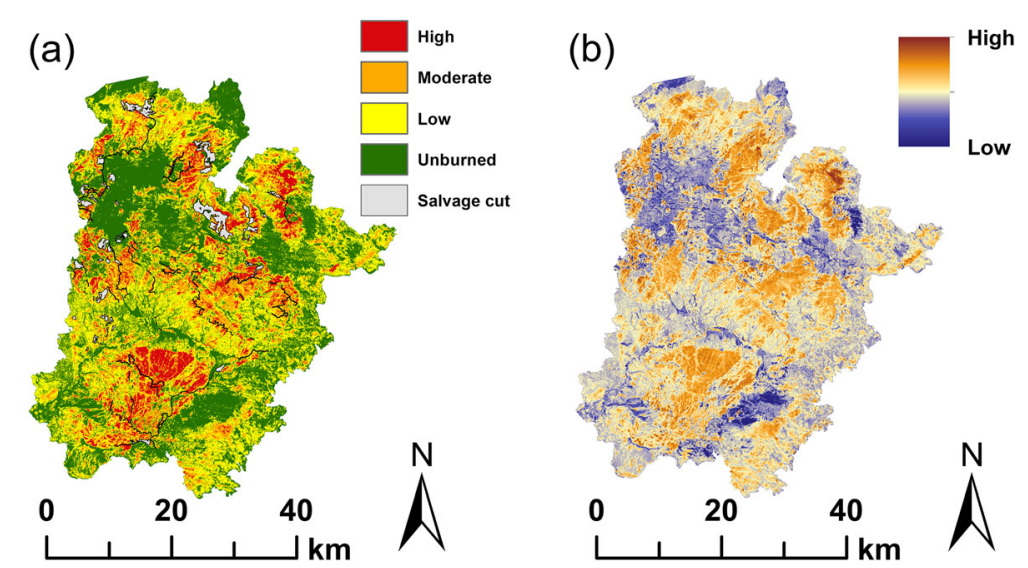

Fig. 2 Burn severity mosaic within the 2011 Wallow Fire, Arizona, USA, depicted by (a) the categorical burn severity map, and (b) the relative differenced normalized burn ratio (RdNBR). Data from MTBS database (US Geological Survey 2017). Warmer color indicates higher severity 
We used RdNBR to evaluate spatial patterns of burn severity and for conducting regression analyses.

\section{Pre- and post-fire predicted nesting habitat suitability}

We focused our habitat modeling effort on Mexican spotted owl nesting habitat for four reasons. First, these owls are most selective for nesting habitat, and appear to forage in a wide variety of habitats around those nesting habitats (Ganey and Balda 1994; Ganey et al. 1999; Ganey et al. 2003). Consequently, nesting habitat is explicitly assumed to be a key factor limiting the distribution of Mexican spotted owls (US Department of Interior 2012). Second, we had access to spatially accurate pre-fire nest location data, whereas we did not have access to spatially accurate foraging locations to facilitate developing habitat models based on foraging habitat. Third, nesting habitat is a delineated area in the recovery plan with highly specific management recommendations. Fourth, nesting habitat is typically less common or available on the study landscape.

We also focused on modeling changes in predicted habitat suitability relative to spatial scale, rather than on direct measures of owl response, for several reasons. First, no rigorous data were available directly measuring owl response to fire. Second, although several studies have used occupancy rates or reproduction shortly after fires to measure owl response (Bond et al. 2002; Jenness et al. 2004; Roberts et al. 2011; Lee et al. 2012; Lee and Bond 2015), these responses may not accurately reflect longer-term changes in habitat quality and owl demography. For example, spotted owls typically show high site fidelity (Forsman et al. 2002; Blakesley et al. 2006; Ganey et al. 2014b), and resident owls may therefore continue to occupy territories immediately following fire even if the habitat within those territories is severely degraded (Ganey et al. 2017). More importantly, recent data on movements of Global Positioning System-tagged California spotted owls suggest that, at least for that subspecies, occupancy rates estimated based on locations of unmarked owls may badly overestimate true occupancy rates (Berigan et al. 2018; Blakey et al. 2019). Further, in a long-term study involving uniquely marked northern spotted owls, Rockweit et al. (2017) found that occupancy rates in severely burned territories remained relatively high over time, but survival rates in these territories were lower and turnover rates were higher than in unburned or lightly burned territories. Finally, Franklin et al. (2000) demonstrated tradeoffs among vital rates in northern spotted owls, with certain landscape patterns fostering high survival while others fostered high reproduction.

Collectively, these studies suggest that: spotted owl response to changes in landscape configuration is complex; short-term measures of parameters such as occupancy and reproductive rates are inadequate to understand that response; and fully understanding the effects of fire will therefore require long-term studies of owl demography using marked individuals. In the absence of such data, our focus on predicted habitat provides interim data on potential changes in habitat suitability, and allowed us to explicitly evaluate the effect of spatial scale on response patterns.

Following Wan et al. (2019a), we applied a previously developed and validated Mexican spotted owl habitat model to our study area, but incorporated Geographic Information System (GIS) data from different years to evaluate pre- and post-fire predicted habitat suitability (note that all future references to "habitat suitability" refer to these model predictions, to avoid continual use of the word "predicted"). This "combined" model averaged the predictions of two multi-scale, optimized habitat selection models. One of these models was developed in the geographic area that included the Wallow Fire (Timm et al. 2016), and the second model was developed in the Sacramento Mountains, New Mexico (Wan et al. 2017). Both models were developed based on locations of resident owls in large landscapes that included areas with and without recent fire histories. Thus, the models were explicitly based on where owls nested in landscapes that allowed them to choose either burned or unburned areas. This combined model performed well in validation tests using independent owl location data (i.e., locations not used in model development) within our study area (AUC $=0.90, r_{\mathrm{s}}$ of area adjusted frequency $=0.81$; Wan et al. 2019a).

The combined model contained 12 habitat variables that quantified forest composition, topography, and climate at nest and roost sites of Mexican spotted owls (Table 1). In model development, each habitat variable was first analyzed separately across multiple spatial scales, to identify the "optimal" scale that best explained owl occurrences, using model selection with Akaike Information Criterion corrected for small sample (AICc). Variables then were included in the multivariate model at their "optimal" scale (i.e., scale was allowed to vary among variables in the multivariate model; see Timm et al. 2016 and Wan et al. 2017, 2019a for details).

Wan et al. (2019a) used LANDFIRE GIS data from 2001 to develop forest composition variables (LANDFIRE 2014). Here, we replaced those data with LANDFIRE GIS data from immediately before (2010) and shortly after (2014) the Wallow Fire to develop the forest composition variables (Additional file 1) in the pre- and post-fire habitat models, respectively, because these were the years closest to the occurrence of the fire for which LANDFIRE data were available. Thus, our pre-fire habitat model depicted habitat suitability one year before the fire, and our post-fire habitat 
Table 1 Habitat variables and data sources for modeling pre(2010) and post-fire (2014) nesting habitat suitability of Mexican spotted owl at the 2011 Wallow Fire, Arizona, USA

\begin{tabular}{|c|c|c|c|}
\hline \multirow[b]{2}{*}{ Habitat variable } & \multirow[b]{2}{*}{ Type } & \multicolumn{2}{|l|}{ Data source } \\
\hline & & Pre fire & Post fire \\
\hline $\begin{array}{l}\text { Percent canopy } \\
\text { cover (\%) }\end{array}$ & Composition & $\begin{array}{l}\text { LANDFIRE } \\
(2010)\end{array}$ & $\begin{array}{l}\text { LANDFIRE } \\
(2014)\end{array}$ \\
\hline \multicolumn{4}{|l|}{$\begin{array}{l}\text { Forest edge } \\
\text { density }\left(\mathrm{m} \mathrm{ha} \mathrm{h}^{-1}\right)\end{array}$} \\
\hline \multicolumn{4}{|l|}{$\begin{array}{l}\text { Percent cover } \\
\text { of mixed- } \\
\text { conifer (\%) }\end{array}$} \\
\hline \multicolumn{4}{|l|}{$\begin{array}{l}\text { Percent cover } \\
\text { of ponderosa } \\
\text { pine (\%) }\end{array}$} \\
\hline \multicolumn{4}{|l|}{$\begin{array}{l}\text { Proximity index } \\
\text { of forest (no unit) }\end{array}$} \\
\hline Slope (degree) & Topographic & LANDFIRE & \\
\hline \multicolumn{4}{|l|}{$\begin{array}{l}\text { Topographic } \\
\text { position index } \\
\text { (no unit) }\end{array}$} \\
\hline \multicolumn{4}{|l|}{$\begin{array}{l}\text { Topographic } \\
\text { roughness } \\
\text { index (no unit) }\end{array}$} \\
\hline \multicolumn{4}{|l|}{ Elevation (m) } \\
\hline $\begin{array}{l}\text { Solar radiation } \\
\text { index (no unit) }\end{array}$ & Climate & $\begin{array}{l}\text { PRISM Climate } \\
\text { Group (2014) }\end{array}$ & \\
\hline \multicolumn{4}{|l|}{$\begin{array}{l}\text { Monsoon-season } \\
\text { precipitation }(\mathrm{mm})\end{array}$} \\
\hline $\begin{array}{l}\text { Cumulative } \\
\text { degree-days } \\
\text { (no unit) }\end{array}$ & & & \\
\hline
\end{tabular}

model depicted habitat suitability about three years after the fire. We assumed that this period provided sufficient time for important immediate post-fire changes (i.e., tree mortality, needle fall, etc.) in habitat to occur. This assumption is generally supported by the fact that tree mortality rates of white fir $(57 \%)$ and Douglas-fir (55\%) in the study area (Waltz et al. 2014) had either matched or exceeded the 3-year tree mortality rates observed by Hood et al. (2007). However, it is unclear whether trees were still dying after the 3-year period. Note that only forest composition variables differed between pre-and post-fire landscapes, so that all change in habitat suitability resulted from change in forest composition variables (Fig. S1).

The models produced maps of habitat suitability scaled between 0 and 1 in each pixel, with higher values indicating greater habitat suitability. We calculated the mean habitat suitability of pre- and post-fire landscapes, as well as pre- and post-fire habitat suitability in unburned, low-, moderate-, and high-severity burned areas as defined by the MTBS categorical burn-severity map. We calculated the pixel-by-pixel absolute change in habitat suitability between pre and post fire using:

Absolute change in habitat suitability $=H S_{\text {post }}-H S_{\text {pre }}$

and percent change in habitat suitability between pre and post fire using:

Percent change in habitat suitability $=\frac{\left(H S_{\text {post }}-H S_{\text {pre }}\right)}{H S_{\text {pre }}}$

where $H S_{\text {pre }}$ and $H S_{\text {post }}$ represented pre- and post-fire habitat suitability, respectively.

Effect of scale on relationships between burn severity and habitat suitability

We evaluated the effect of spatial scale on relationships between burn severity and pre-fire habitat suitability by generating 1000 random sample points stratified across the four burn-severity classes (i.e., there were 250 points within high-, moderate-, low-severity, and unburned patches, respectively). We extracted the mean values of RdNBR, pre-fire habitat suitability, and percent change in habitat suitability around each sample point at 41 different scales (a single-pixel scale at $30 \mathrm{~m} \times 30 \mathrm{~m}$, and 40 scales ranging from 100 to $4000 \mathrm{~m}$ radii at increments of $100 \mathrm{~m})$. At each scale, we used either simple linear regression or logarithmic regression (whichever provided the best model fit) to evaluate the relationship between (1) the RdNBR and percent change in habitat suitability, and (2) the RdNBR and pre-fire habitat suitability. We calculated and compared the adjusted $R^{2}$ and beta coefficients (slope of the regression line) for all models, and identified the optimal spatial scale for each of these relationships as the scale that maximized the relationship.

\section{Spatial change in forest composition}

We assessed spatial change in forest composition variables to visualize which variable was most related to the post-fire spatial patterns of habitat suitability change. This was done by subtracting the pre-fire layer in 2010 from the post-fire layer in 2014 for each forest composition variable.

\section{Results}

Spatial pattern in pre- and post-fire habitat suitability

Pre- and post-fire maps of habitat suitability were qualitatively similar in terms of general spatial pattern. In both maps, areas of relatively high habitat suitability were concentrated in the southern and northeastern portions of the study area, and typically occurred along deep, narrow canyons and valleys, with generally lower 

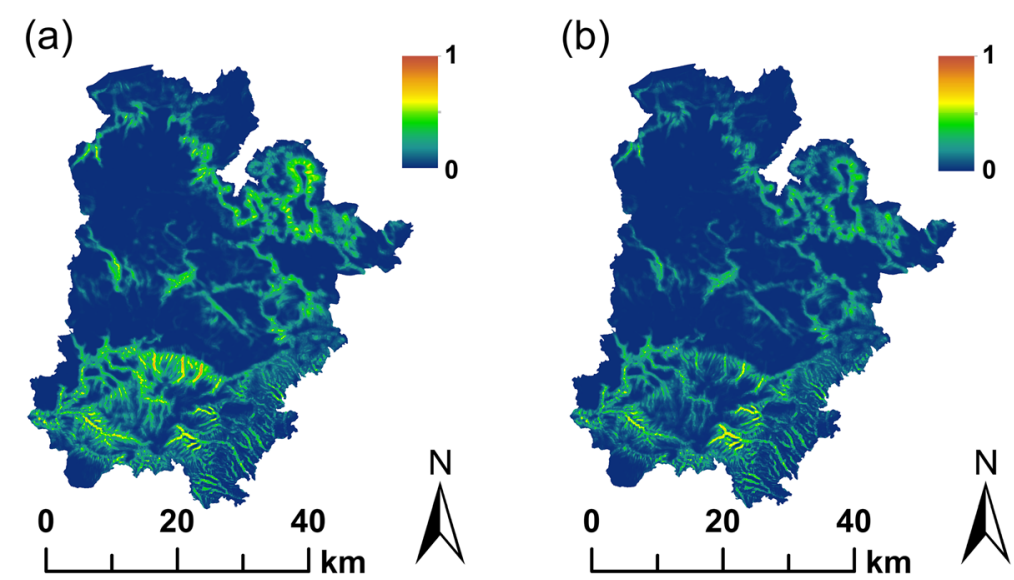

Fig. 3 Habitat suitability maps depicting (a) pre-fire (2010) and (b) post-fire (2014) suitability of Mexican spotted owl nesting habitats within the perimeter of the 2011 Wallow fire, Arizona, USA. Warm color indicates high suitability; cool color indicates low suitability. Habitat suitability predictions were based on a composite model created by averaging the predictions of two individual models developed by Timm et al. (2016) and Wan et al. (2017)

suitability throughout most of the central portion of the study area (Fig. 3). The major change between pre- and post-fire maps was a relatively substantial decline in habitat suitability across much of the landscape. The primary exception occurred in the southeastern portion of the study area, where post-fire suitability remained similar or even increased in some areas. Some patches of nesting habitat remained even in areas that sustained high-severity fire, but those patches typically were smaller, more fragmented, and had lower habitat suitability relative to their pre-fire condition (Fig. 3).

\section{Change in habitat suitability}

Mean habitat suitability of the study area decreased by $21.9 \%$ three years after the fire (Table 2; note that the overall low averages for habitat suitability across the table were due to most pixels having a value near zero). Absolute and percent change in habitat suitability between preand post-fire periods was spatially variable (Fig. 4), with absolute change ranging from -39.8 to $+15.6 \%$, and percent change ranging from -84 to $+216 \%$ (Fig. 4).

The spatial pattern of change in habitat suitability generally followed the mosaic patterns of burn severity. Habitat suitability generally decreased substantially in areas that burned at high severity, but often remained the same or increased in areas that burned at low severity (Figs. 2 and 4). Mean habitat suitability decreased by 10.9, 19.8, 34.2 , and $48.8 \%$ across unburned, low-severity, moderateseverity, and high-severity patches, respectively. Most areas that increased in habitat quality, and all of those with a large percentage increase, were of very low suitability both before and after the fire. Thus, the large increase in percent suitability in these areas was driven more by the effect of a small denominator than by a large absolute change in predicted suitability.

Pre-fire habitat suitability was positively related to subsequent burn severity, indicating that areas of high suitability were more likely to experience high burn severity than areas with lower pre-fire suitability (Fig. 5). This relationship was significant but relatively weak, however (Fig. 5).

\section{Effect of scale on relationships between burn severity and habitat suitability}

Relationships between burn severity and change in habitat suitability varied with spatial scale. Change in habitat suitability was slightly positively related to burn severity at the scale of individual pixels $\left(R^{2}=0.02, P<0.001\right.$;

Table 2 Mean pre- (2010) and post-fire (2014) habitat suitability, and mean absolute and percent change of habitat suitability for the overall study area and by burned severity class as defined by the MTBS burned severity map (US Geological Survey 2017) at the 2011 Wallow Fire, Arizona, USA. Suitability is an index with higher values indicating higher suitability. Standard errors are shown ( \pm )

\begin{tabular}{lllll}
\hline Burn severity & Pre-fire suitability & Post-fire suitability & Absolute change & Percent change (\%) \\
\hline Overall & $0.065 \pm 0.003$ & $0.048 \pm 0.003$ & $-0.017 \pm 0.000$ & $-21.9 \pm 1.3$ \\
Unburned & $0.047 \pm 0.000$ & $0.043 \pm 0.007$ & $-0.004 \pm 0.000$ & $-10.9 \pm 2.1$ \\
Low-severity burned & $0.059 \pm 0.000$ & $0.047 \pm 0.007$ & $-0.012 \pm 0.000$ & $-19.8 \pm 1.7$ \\
Moderate-severity burned & $0.088 \pm 0.001$ & $0.057 \pm 0.011$ & $-0.031 \pm 0.000$ & $-34.2 \pm 2.5$ \\
High-severity burned & $0.112 \pm 0.001$ & $0.056 \pm 0.012$ & $-0.055 \pm 0.000$ & $-48.8 \pm 3.0$ \\
\hline
\end{tabular}



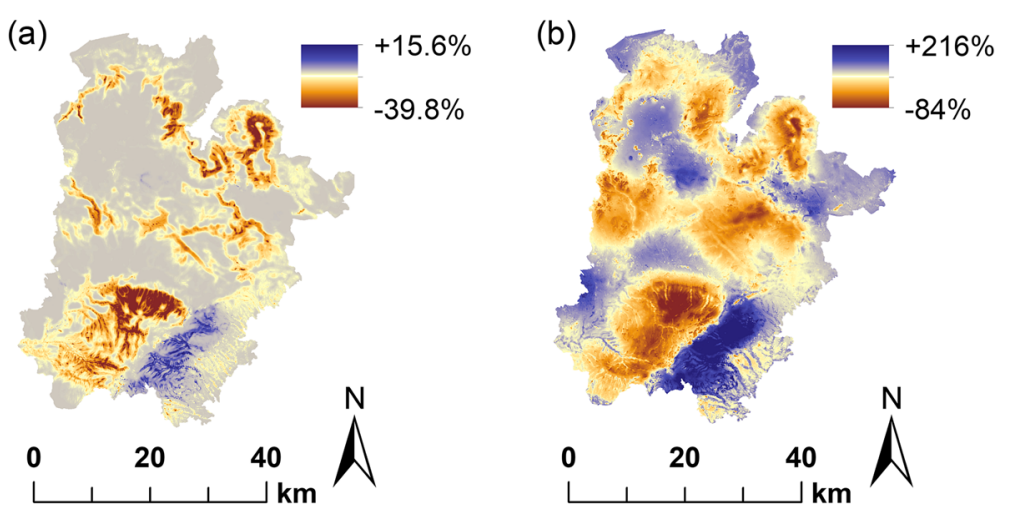

Fig. 4 (a) Absolute and (b) percent change in predicted habitat suitability between pre- and post-fire landscapes within the perimeter of the 2011 Wallow Fire, Arizona, USA. Warm color indicates percent decrease in habitat suitability; cool color indicates percent increase in habitat suitability. Habitat suitability predictions were based on a composite model created by averaging the predictions of two individual models developed by Timm et al. (2016) and Wan et al. (2017)

Fig. 6). At all other scales, change in habitat suitability was significantly $(P<0.001)$ and negatively related to burn severity. This relationship generally increased with spatial scale and peaked at the scale of $3300 \mathrm{~m}$ radius $\left(R^{2}=0.65\right.$; Figs. 6 and 7$)$.

Relationships between burn severity and pre-fire habitat suitability also varied with spatial scale. At the singlepixel scale (i.e., $30 \mathrm{~m} \times 30 \mathrm{~m}$ ), this relationship was statistically nonsignificant $(P=0.11)$. Across all other scales, pre-fire habitat suitability was significantly but weakly positively related to burn severity $(P<0.001)$, with that relationship peaking at the scale of $2100 \mathrm{~m}$ radius $\left(R^{2}=0.20\right.$; Figs. 5 and 6$)$.

\section{Spatial change in forest composition and habitat suitability}

Pre- and post-fire differences in percent canopy cover and percent mixed-conifer (Fig. 8a and c) appeared to be the leading factors driving changes in habitat suitability (Fig. 4). Percent ponderosa pine also appeared to play a role, but the alignment of spatial pattern with habitat

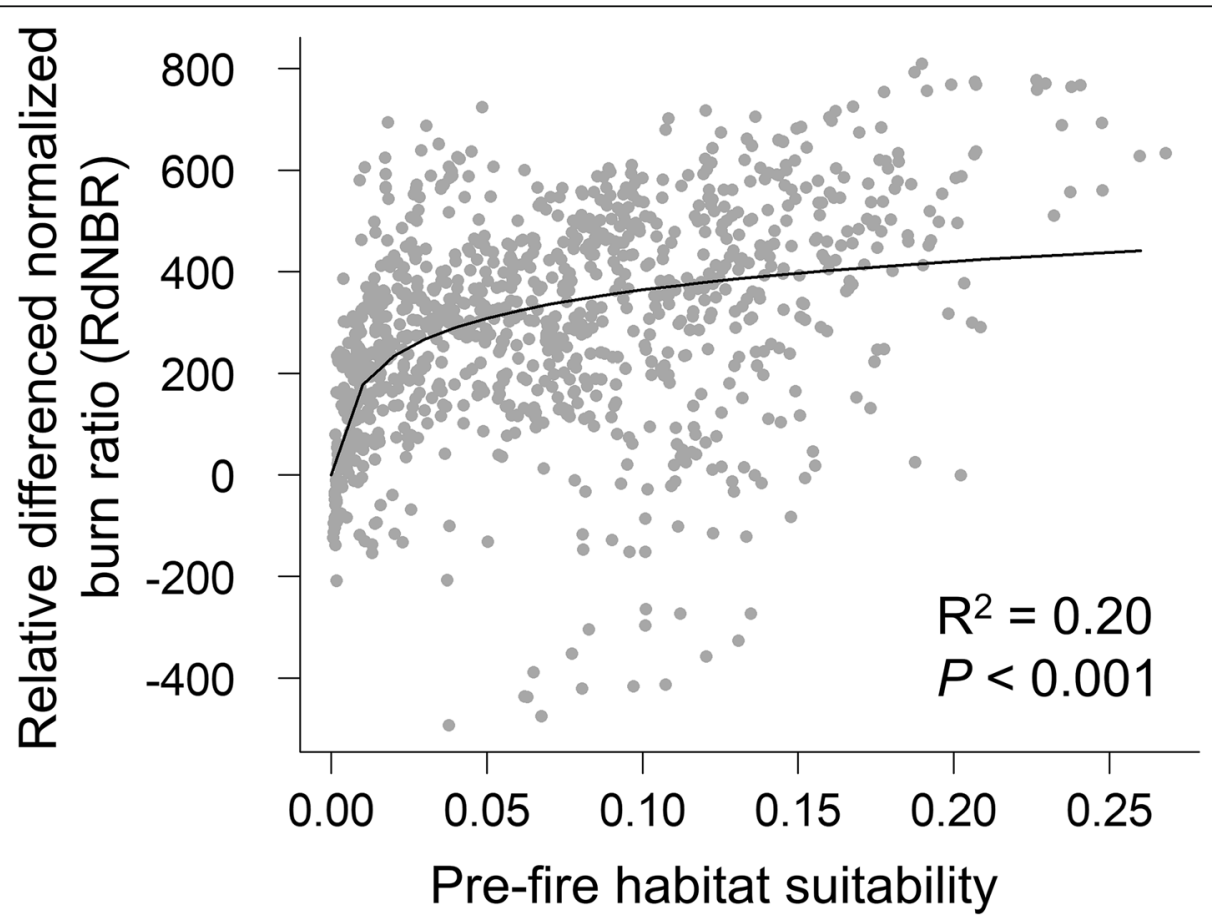

Fig. 5 Logarithmic regression showing a weak but significant relationship between pre-fire habitat suitability and burn severity of the 2011 Wallow Fire, Arizona, USA. Gray markers (dots) represent values measured at the optimal scale for this relationship (2100 m radius). Black line represents the regression line 

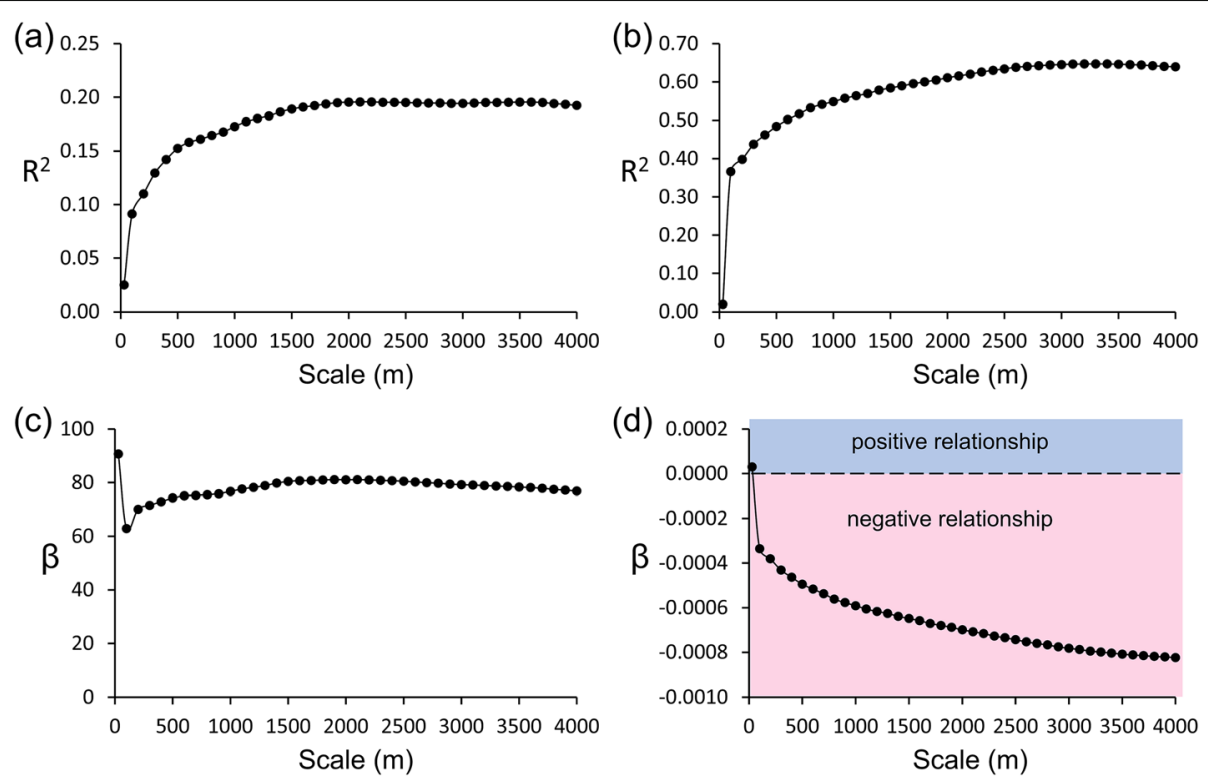

Fig. 6 Scalogram showing the effect of varying spatial extent on the strength of relationships based on linear regression model. Panels (a) and (c) show $R^{2}$ and beta coefficient ( $\beta$ ) for the relationship between pre-fire Mexican (2010) spotted owl habitat suitability and burn severity at the 2011 Wallow Fire, Arizona, USA. Panels (b) and (d) show $R^{2}$ and beta coefficient for the relationship between burn severity (i.e., RdNBR) and percent change in habitat suitability for Mexican spotted owl at the 2011 Wallow Fire, Arizona, USA

suitability change was not as clear (Fig. 8d). Forest edge density and proximity were not strongly affected by fire and therefore were not major factors influencing spatial change in habitat suitability (Fig. $8 \mathrm{~b}$ and e).

\section{Discussion}

Our results indicated that the Wallow Fire reduced habitat suitability for Mexican spotted owls across much of the landscape, and that reduction was greatest in areas that burned at high severity (decreased by as much as $39.8 \%$; Fig. 4a). Those results also indicated that fire effects on nesting habitat suitability for Mexican spotted owls varied spatially, with that variation apparently influenced by spatial heterogeneity in burn severity and consequent changes in forest structure. The clearest example of this occurred in the southern portion of the study area. Burn

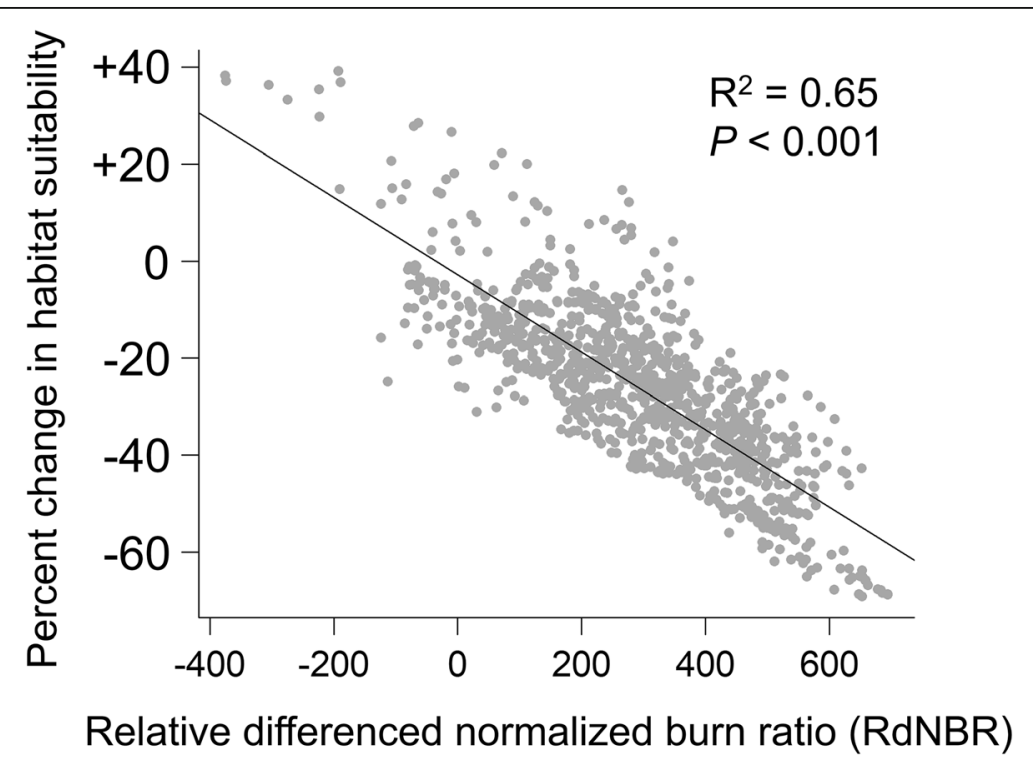

Fig. 7 Simple linear regression showing that habitat suitability decreased with increased burn severity within the 2011 Wallow Fire, Arizona, USA. Gray markers (dots) represent values measured at the optimized scale (3300 m radius). Black line represents the regression line 


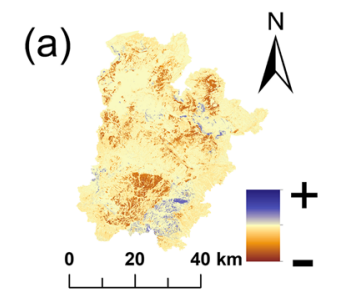

(b)

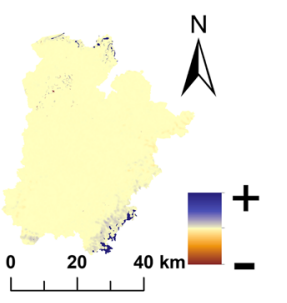

(c)

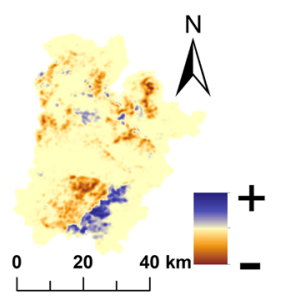

(d)

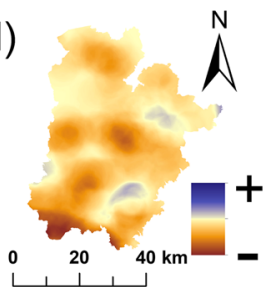

(e)

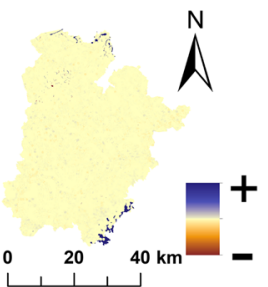

Fig. 8 Spatial change in forest composition variables between pre- and post-fire landscapes within the perimeter of the 2011 Wallow Fire, Arizona, USA: (a) percent canopy cover, (b) forest edge density, (c) percent cover of mixed-conifer, (d) percent cover of ponderosa pine, and (e) proximity index of forest. Warm color indicates a decrease; cool color indicates an increase

severity was highly uneven across this area (Fig. 2), resulting in large spatial variation in percent change in habitat suitability (Fig. 4).

Our results also indicated that areas of high habitat suitability were more likely to burn at high severity than areas of low habitat suitability (Table 2; Fig. 5). These high-suitability areas may have been more prone to high-severity fire for multiple reasons. Mexican spotted owls selectively nest in mixed-conifer forests featuring high fuel loads or fuel connectivity (Seamans and Gutiérrez 1995; May et al. 2004; Ganey et al. 2016). These productive mixed-conifer forests generally naturally have higher forest density and fuel loading than other Southwestern forest types, making them more vulnerable to high-severity fire (Sackett and Haase 1996). Also, there is some evidence that these forest types may also have had larger increase in fuel load due to fire suppression than other forest types (Fulé et al. 2004; O'Connor et al. 2014; Waltz et al. 2014; Roccaforte et al. 2015), which may further increase their susceptibility to high-severity fire. Topography also may influence the relationship between prefire habitat suitability and burn severity, however. Mexican spotted owls frequently nest on or adjacent to steep slopes (Seamans and Gutiérrez 1995; May et al. 2004; Ganey et al. 2016), and steep topography also can increase fire severity (Dillon et al. 2011; Birch et al. 2015). Numerous other factors also can affect burn severity, including weather, wind speed and direction, and suppression efforts, but these factors are not as tightly associated with spotted owl nesting habitat as are forest structure and topography (Timm et al. 2016; Wan et al. 2017).

Regardless of the underlying reasons, the finding that pre-fire habitat suitability is positively related to fire severity suggests that the effects of high-severity fire may be greater in Mexican spotted owl nesting habitat than in the overall landscape. This study thus adds to emerging evidence that large, high-severity fire poses a potential threat to the Mexican spotted owl (Jones et al. 2016; Stephens et al. 2016). Like most fire studies on the spotted owl, we evaluated only the short-term effects of fire (Ganey et al. 2017). At the time of this study, 2014 LANDFIRE data was the latest available data and, therefore, three years was the maximum possible post-fire period for the analysis. As noted, we assumed that this provided a sufficient time period for many immediate post-fire changes (i.e., tree mortality, needle fall, etc.) in habitat to occur. Nevertheless, future studies should address the long-term effects of high-severity fire on the spotted owl, as well as the recovery of spotted owl habitat from high-severity fire over longer periods that match or exceed the life span of the species. Our models provide an objective and repeatable means to accomplish periodic reassessments of habitat suitability and recovery in this post-fire landscape, but should be coupled with studies of owl demography that are currently lacking in these landscapes.

Notably, we found improved habitat suitability as a result of low-severity fire in parts of the study area. The neutral to positive effect of lower-severity fire on the spotted owl is consistent with previous studies suggesting that such fires had little effect on spotted owls (Bond et al. 2002; Roberts et al. 2011; Lee et al. 2012; Ganey et al. 2014a). Authors of the Mexican spotted owl recovery plan recommended using prescribed and managed fire, intended to burn with low to moderate severity, to reduce risks of high-severity fire and improve prey habitat and food resources (US Department of Interior 2012). Our results generally support that strategy. Despite decreases in mean habitat suitability even in unburned and low-severity patches, such decreases are considerably lower than the moderate- and high-severity 
patches, suggesting short-term tradeoffs and possibly reducing overall risk for higher-severity fires in the future. Existing studies on the response of Mexican spotted owls to fire remain few, however. Replicated studies on different types of fires (e.g., size, severity, recurring, etc.), covering broader geographic areas and different types of landscapes, and including measures of demography based ideally on marked owls, are needed to sufficiently evaluate the risks and benefits of prescribed fire treatments and managed fires (Ganey et al. 2017). Until such data are available, however, our models provide an objective and repeatable means to assess the effects of such fires on predicted habitat suitability at varying spatial and temporal scales.

\section{Importance of scale in quantifying fire impacts}

Relating natural phenomena across spatial scales is a classical problem in ecology (Levin 1992), yet empirical research has been slow to fully embrace the challenge (Chave 2013; McGarigal et al. 2016). To our knowledge, this is the first study that has adopted a scale optimization approach to quantify relationships between burn severity and habitat change. By measuring habitat suitability and burn severity along a wide range of continuous scales, we demonstrated that the dominant scale of effect (Grand et al. 2004; Jackson and Fahrig 2015; McGarigal et al. 2016) could be statistically identified, and that quantifying patterns of variability across scales was important in understanding the magnitude of fire effects on changes in habitat suitability. For example, the single-pixel scale showed a weak positive relationship between burn severity and change in habitat suitability, whereas this relationship was strongly negative at all other scales, and had much stronger effects at the optimal scale of $3300 \mathrm{~m}$ (Fig. 6d). Relationships between burn severity and pre-fire habitat suitability also varied in magnitude across spatial scales, with beta coefficients for this relationship at larger scales more than double those at smaller scales (Fig. 6d). Our results support a recommendation made by Levin (1992) that, in choosing the scale of analysis, scientists should shift attention from unpredictable stochastic phenomena at fine scales to more generalizable patterns at broader scales. Overall, our results revealed that fire studies that do not account explicitly for the effects of spatial scale may produce inaccurate and unreliable estimates of true fire impacts on species habitats.

The scale of effect has largely been neglected in fire and spotted owl studies (but see Bond et al. 2016). Even when the landscape remains the same, the measurable patterns can vary depending upon the spatial scales chosen for the analysis. Thus, differences in spatial scales across studies can be one factor explaining the inconsistent results about the relationship between fire and spotted owl habitat (Ganey et al. 2017). Many factors can lead to inconsistent scales being used across different analyses. In this study, we tested a series of spatial scales by varying the extent of search neighborhoods in quantifying the landscape. Other factors can also cause spatial scales of the analysis to vary (e.g., sampling plot size in the field, spatial resolution [i.e., pixel size] of GIS layer used, etc.). Finally, while spatial scaling is the focus in this study, variations in temporal scaling across studies can also introduce inconsistencies (Schooley 1994). Thus, it is important to consider potential inconsistencies that can result from these factors when comparing results across studies.

\section{Limitations of this study}

Several factors limit the inference possible from this study. First, as noted, we focused on changes in habitat suitability, and our habitat models focused on forested nesting habitat. Fire may have positive effects on foraging habitat (Converse et al. 2006; Amacher et al. 2008; Roberts et al. 2015; Bond et al. 2016), at least in the short term, and such effects could potentially partly compensate for reductions in habitat suitability for nesting. Second, our analyses focused on a single time period, and did not account for potential longer-term changes in habitat. Related to this, our analysis applied a single model that was optimized across two broadextent study areas to both pre- and post-fire landscapes. However, it is well known that habitat associations can change dramatically from pre to post disturbance when the disturbance results in changes in the limiting factors that drive patterns of distribution, abundance, and occurrence (Cushman et al. 2011). Further work should explore this temporal non-stationarity issue by building different spatially optimized models based on occurrence data before and after disturbances, ideally repeatedly over several decades following disturbance to address time lag effects (Ganey et al. 2017). Most importantly, our analyses did not include direct data on owl response to fire. As noted earlier, that response may involve complex interrelationships among landscape pattern and vital rates, and those relationships may change over time as well as differ between pre- and post-fire landscapes. Consequently, fully understanding how fire, especially high-severity fire, affects Mexican spotted owls will require long-term studies of demography of marked individuals in post-fire landscapes (Ganey et al. 2017; Wan et al. 2018a, 2018b), supplemented by long-term studies of post-fire habitat recovery. Until such data are available, however, our modeling results provide an objective and repeatable means to evaluate the effect of fire on habitat suitability, the relationship between pre-fire habitat suitability and burn severity, and the effect of spatial scale on both relationships. 


\section{Management implications}

Our results suggest that high-severity fire can decrease habitat suitability considerably for nesting Mexican spotted owls. They also suggest that areas with high habitat suitability for nesting may be more prone to high-severity fire, and that both relationships are strongest at large spatial scales. These results generally support previous analyses suggesting that large high-severity fires may threaten spotted owls and their habitat (Jones et al. 2016; Jones et al. 2019; Rockweit et al. 2017). They also suggest that efforts to reduce the risk of high-severity fire in owl nesting habitat, including activities such as prescribed fire, managed fire, and fuels-reduction treatments, should be cautiously explored, especially when placed strategically around, but not necessarily in, nesting habitat, to reduce risk of high-severity fire within the nesting habitat (e.g., US Department of Interior 2012; Waltz et al. 2014; Roccaforte et al. 2015; Chiono et al. 2017; Ziegler et al. 2017). Finally, they suggest that fire impacts on the spotted owl should be evaluated at scales broader than nest sites or Protected Activity Centers (US Department of Interior 2012). These broader scales may correspond to owl home ranges or territories (Ganey et al. 1999, 2005; Willey and van Riper 2007).

Our results also demonstrate the importance of considering spatial scales in evaluating fire effects on natural resources and wildlife habitat. Studies that do not explicitly consider spatial scale in evaluating these effects may produce misleading and biased results. Consequently, we recommend that future studies of fire effects use multi-scale analytical techniques.

\section{Supplementary information}

Supplementary information accompanies this paper at https://doi.org/10 1186/s42408-020-0068-2.

Additional file 1. Pre- (2010) and post-fire (2014) composition variables at the 2011 Wallow Fire, Arizona, USA

\section{Acknowledgements}

We thank C. Vojta, C. Aslan, and P. Fulé for providing constructive comments for improving the project.

\section{Authors' contributions}

HW conceptualized, designed, and carried out the study. HW and JG drafted and revised the manuscript. JG and SC acquired funding. SC supervised the research. All authors read and approved the final manuscript.

\section{Funding}

This research was supported by funding from the Joint Fire Sciences Project and the National Fire Plan.

\section{Availability of data and materials}

Only freely and publicly available datasets were used in this study. Data sources were described in the paper.

Ethics approval and consent to participate Not applicable.
Consent for publication

Not applicable.

\section{Competing interests}

The authors declare that they have no competing interests.

\section{Author details}

${ }^{1}$ School of Public and Community Health Sciences, University of Montana, 32 Campus Drive, Missoula, Montana, USA. ${ }^{2}$ USDA Forest Service Rocky Mountain Research Station, 2500 S. Pine Knoll, Flagstaff, Arizona, USA

Received: 11 November 2019 Accepted: 17 February 2020

Published online: 12 March 2020

\section{References}

Agee, J.K. 1993. Fire Ecology of Pacific Northwest Forests, 493. Washington, D.C.: Island Press.

Amacher, A.J., R.H. Barrett, J.J. Moghaddas, and S.L. Stephens. 2008. Preliminary effects of fire and mechanical fuel treatments on the abundance of small mammals in the mixed-conifer forest of the Sierra Nevada. Forest Ecology and Management 255: 3193-3202. https://doi.org/10.1016/j.foreco.2007.10.059.

Attiwill, P., and D. Binkley. 2013. Exploring the mega-fire reality: a 'forest ecology and management' conference. Forest Ecology and Management 294: 1-3. https://doi.org/10.1016/j.foreco.2012.12.025.

Baker, W.L. 2015a. Are high-severity fires burning at much higher rates recently than historically in dry-forest landscapes of the western USA? PLoS One 10 (9): e0136147. https://doi.org/10.1371/journal.pone.0136147.

Baker, W.L. 2015b. Historical northern spotted owl habitat and old-growth dry forests maintained by mixed-severity wildfires. Landscape Ecology 30: 655666. https://doi.org/10.1007/s10980-014-0144-6.

Balch, J.K., B.A. Bradley, C.M. D'Antonio, and J. Gómez-Dans. 2013. Introduced annual grass increases regional fire activity across the arid western USA (1980-2009). Global Change Biology 19: 173-183. https://doi.org/10.1111/gcb.12046.

Balch, J.K., B.A. Bradley, J.T. Abatzogloue, R. Chelsea Nagya, E.J. Fuscod, and A.L. Mahooda. 2017. Human-started wildfires expand the fire niche across the United States. Proceedings National Academy of Sciences 114: 2946-2951. https://doi.org/10.1073/pnas.1617394114.

Barbero, R., J.T. Abatzoglou, N.K. Larkin, C.A. Kolden, and B. Stocks. 2015. Climate change presents increased potential for very large fires in the contiguous United States. International Journal of Wildland Fire 24: 892-899. https://doi.org/10.1071/WF15083.

Berigan, W.J., G.M. Jones, S.A. Whitmore, R.J. Gutiérrez, and M.Z. Peery. 2018. Cryptic wide-ranging movements lead to upwardly biased occupancy in a territorial species. Journal of Applied Ecology 56: 470-480. https://doi.org/10. 1111/1365-2664.13265.

Birch, D.S., P. Morgan, C.A. Kolden, J.T. Abatzoglou, G.K. Dillon, A.T. Hudak, and A. M.S. Smith. 2015. Vegetation, topography and daily weather influenced burn severity in central Idaho and western Montana forests. Ecosphere 6 (1): 17. https://doi.org/10.1890/ES14-00213.1.

Blakey, R.V., R.B. Siegel, E.B. Webb, C.P. Dillingham, R.L. Bauer, M. Johnson, and D. C. Kesler. 2019. Space use, forays, and habitat selection by California Spotted Owls (Strix occidentalis occidentalis) during the breeding season: New insights from high resolution GPS tracking. Forest Ecology and Management 432: 912-922. https://doi.org/10.1016/j.foreco.2018.10.017.

Blakesley, J.A., D.R. Anderson, and B.R. Noon. 2006. Breeding dispersal in the California spotted owl. Condor 108: 71-81. https://doi.org/10.1093/condor/ 108.1.71.

Bond, M.L. 2016. The heat is on: spotted owls and wildfire. Reference module in earth systems and environmental sciences. Amsterdam. http://www. sciencedirect.com/science/article/pii/B9780124095489100144. Accessed 15 Mar 2018: Elsevier Press. https://doi.org/10.1016/B978-0-12-409548-9.10014-4.

Bond, M.L., C. Bradley, and D.E. Lee. 2016. Foraging habitat selection by California spotted owls after fire. Journal of Wildlife Management 80: 1290-1300. https://doi.org/10.1002/jwmg.21112.

Bond, M.L., F.J. Gutiérrez, A.B. Franklin, W.S. LaHaye, C.A. May, and M.E. Seamans. 2002. Short-term effects of wildfires on spotted owl survival, site fidelity, mate fidelity, and reproductive success. Wildlife Society Bulletin 30: 1022-1028.

Cal Fire (2018) Top 20 largest California wildfires. http://www.fire.ca.gov/ communications/downloads/fact_sheets/Top20_Acres.pdf. Accessed 15 Mar 2018. 
Cansler, C.A., and D. McKenzie. 2012. How robust are burn severity indices when applied in a new region? Evaluation of alternate field-based and remote-sensing methods Remote Sensing 4 (2): 456-483. https://doi.org/10.3390/rs4020456.

Chave, J. 2013. The problem of pattern and scale in ecology: what have we learned in 20 years? Ecology Letters 16: 4-16. https://doi.org/10.1111/ele.12048.

Chiono, L.A., D.L. Fry, B.M. Collins, A.H. Chatfield, and S.L. Stephens. 2017. Landscape-scale fuel treatment and wildfire impacts on carbon stocks and fire hazard in California spotted owl habitat. Ecosphere 8 (1): e01648. https://doi.org/10.1002/ecs2.1648.

Converse, S.J., W.M. Block, and G.C. White. 2006. Small mammal population and habitat responses to forest thinning and prescribed fire. Forest Ecology and Management 228: 263-273. https://doi.org/10.1016/j.foreco.2006.03.006.

Cushman, S.A., M.G. Raphael, L.F. Ruggiero, A.S. Shirk, T.N. Wasserman, and E. C. O'Doherty. 2011. Limiting factors and landscape connectivity: the American marten in the Rocky Mountains. Landscape Ecology 26: 11371149. https://doi.org/10.1007/s10980-011-9645-8

Dillon, G.K., Z.A. Holden, P. Morgan, M.A. Crimmins, E.K. Heyerdahl, and C.H. Luce. 2011. Both topography and climate affected forest and woodland burn severity in two regions of the western US, 1984 to 2006. Ecosphere 2 (12): 1-33. https://doi.org/10.1890/ES11-00271.1.

Doerr, S.H., and C. Santin. 2016. Global trends in wildfire and its impacts: perceptions versus realities in a changing world. Philosophical Transactions Royal Society B 371: 20150345. https://doi.org/10.1098/rstb.2015.0345.

Earth Observatory (2007) Milford flat fire, Utah. https://earthobservatory.nasa.gov/ NaturalHazards/view.php?id=18693. Accessed 15 Mar 2018.

Eidenshink, J., B. Schwind, K. Brewer, et al. 2007. A Project for Monitoring Trends in Burn Severity. fire eco/ 3: 3-21. https://doi.org/10.4996/fireecology.0301003.

Flannigan, M., A.S. Cantin, W.J. de Groot, M. Wotton, A. Newbery, and L.M. Gowman. 2013. Global wildland fire season severity in the 21 st century. Forest Ecology and Management 293: 54-61. https://doi.org/10.1016/j.foreco.2012.10.022.

Flatley, W.T., and P.Z. Fulé. 2016. Are historical fire regimes compatible with future climate? Implications for forest restoration. Ecosphere 7 (10): e01471. https://doi.org/10.1002/ecs2.1471.

Forsman, E.D., R.G. Anthony, J.A. Reid, P.J. Loschl, S.G. Sovern, M. Taylor, B.L. Biswell, A. Ellingson, E.C. Meslow, G.S. Miller, K.A. Swindle, J.A. Thrailkill, F.F. Wagner, and D.E. Seaman. 2002. Natal and breeding dispersal of northern spotted owls. Wildlife Monographs 149: 1-35.

Franklin, A.B., D.R. Anderson, R.J. Gutiérrez, and K.P. Burnham. 2000. Climate, habitat quality, and fitness in a northern spotted owl population in northwestern California. Ecological Monographs 70: 539-590. https://doi.org/ 10.1890/0012-9615(2000)070[0539:CHQAFI]2.0.CO;2.

Fulé, P.Z., J.E. Crouse, A.E. Cocke, M.M. Moore, and W.W. Covington. 2004. Changes in canopy fuels and potential fire behavior 1880-2040: Grand Canyon, Arizona. Ecological Modelling 175: 231-248. https://doi.org/10.1016/j. ecolmodel.2003.10.023

Ganey, J.L., and R.P. Balda. 1994. Habitat selection by Mexican spotted owls in northern Arizona. Auk 111: 162-169. https://doi.org/10.2307/4088514.

Ganey, J.L., W.M. Block, J.S. Jenness, and R.A. Wilson. 1999. Mexican spotted owl home range and habitat use in pine-oak forest: implications for forest management. Forest Science 45: 127-135. https://doi.org/10.1093/ forestscience/45.1.127.

Ganey, J.L., W.M. Block, and S.H. Ackers. 2003. Structural characteristics of forest stands within home ranges of Mexican spotted owls in Arizona and New Mexico. Western Journal of Applied Forestry 18: 189-198. https://doi.org/10. 1093/wjaf/18.3.189.

Ganey, J.L., W.M. Block, J.P. Ward Jr., and B.E. Strohmeyer. 2005. Home range, habitat use, and vital rates of Mexican spotted owls in two different environments. Southwestern Naturalist 50: 323-333. https://doi.org/10.1894/ 0038-4909(2005)050[0323:HRHUSA]2.0.CO;2.

Ganey, J.L., J.P. Ward Jr., and D.W. Willey. 2011. Status and ecology of Mexican spotted owls in the Upper Gila Mountains Recovery Unit, Arizona and New Mexico. General Technical Report RMRS-GTR-256WWW. Fort Collins: U.S Department of Agriculture, Forest Service, Rocky Mountain Research Station. https://doi.org/10.2737/RMRS-GTR-256

Ganey, J.L., S.C. Kyle, T.A. Rawlinson, D.L. Apprill, and J.P. Ward Jr. 2014a. Relative abundance of small mammals in nest core areas and burned wintering areas of Mexican spotted owls in the Sacramento Mountains, New Mexico. Wilson Journal of Ornithology 126: 47-52. https://doi.org/10.1676/13-117.1.

Ganey, J.L., D.L. Apprill, S.C. Kyle, T.A. Rawlinson, R.S. Jonnes, and J.P. Ward Jr. 2014b. Breeding dispersal of Mexican spotted owls in the Sacramento
Mountains, New Mexico. Wilson Journal of Ornithology 126: 516-524. https://doi.org/10.1676/14-004.1.

Ganey, J.L., J.M. Iníguez, S. Hedwall, W.M. Block, J.P. Ward Jr., R.S. Jonnes, T.A. Rawlinson, S.C. Kyle, and D.L. Apprill. 2016. Evaluating desired conditions for Mexican spotted owl nesting and roosting habitat. Forest Science 62: 457-462.

Ganey, J.L., H.Y. Wan, S.A. Cushman, and C.D. Vojta. 2017. Conflicting perspectives on spotted owls, wildfire, and forest restoration. Fire Ecology 13 (3): 146-165. https://doi.org/10.4996/fireecology.130318020.

Grand, J., J. Buonaccorsi, S.A. Cushman, C.R. Griffin, and M.C. Neel. 2004. A multiscale landscape approach to predicting bird and moth rarity hotspots in a threatened pitch pine-scrub oak community. Conservation Biology 18 (4): 1063-1077. https://doi.org/10.1111/j.1523-1739.2004.00555.x.

Gutiérrez, R.J., P.N. Manley, and P.A. Stine. 2017. The California spotted owl: current status of knowledge, 294. Albany: US Department of Agriculture General technical Report PSW-GTR-254. Pacific Southwest Research Station.

Hanson, C.T., and D.C. Odion. 2016. Historical forest conditions within the range of the Pacific fisher and spotted owl in the central and southern Sierra Nevada, California, USA. Natural Areas Journal 36: 8-19. https://doi.org/10. 3375/043.036.0106.

Hood, S.M., C.W. McHugh, K.C. Ryan, E. Reinhardt, and S.L. Smith. 2007. Evaluation of a post-fire tree mortality model for western USA conifers. International Journal of Wildland Fire 16 (6): 679-689. https://doi.org/10.1071/WF06122.

Jackson, H.B., and L. Fahrig. 2015. Are ecologists conducting research at the optimal scale? Global Ecology and Biogeography 24: 52-63. https://doi.org/10. 1111/geb.12233.

Jenness, J.S., P. Beier, and J.L. Ganey. 2004. Associations between forest fire and Mexican spotted owls. Forest Science 50: 765-772.

Jones, G.M., R.J. Gutiérrez, D.J. Tempel, S.A. Whitmore, W.J. Berigan, and M.Z. Peery. 2016. Megafires: an emerging threat to old-forest species. Frontiers in Ecology and the Environment 14: 300-306. https://doi.org/10.1002/fee.1298.

Jones, G.M., R.J. Gutiérrez, D.J. Tempel, W.J. Berigan, S.A. Whitmore, and M.Z. Peery. 2019. Megafire effects on spotted owls: elucidation of a growing threat and a response to Hanson et al. (2018). Nature Conservation 33: 21-41. https://doi.org/10.3897/natureconservation.33.32741.

Keane, J.J. 2017. Chapter 7: Threats to the viability of California spotted owls. The California Spotted Owl: Current State of Knowledge. In General Technical Report PSW-GTR-254, 185-238. Albany: Pacific Southwest Research Station, Forest Service, U.S. Department of Agriculture.

Keyser, A., and A.L. Westerling. 2017. Climate drives inter-annual variability in probability of high severity fire occurrence in the western United States. Environmental Research Letters 12: 065003. https://doi.org/10.1088/1748-9326/aa6b10.

Kitzberger, T., D.A. Falk, A.L. Westerling, and T.W. Swetnam. 2017. Direct and indirect climate controls predict heterogeneous early-mid 21st century wildfire burned area across western and boreal North America. PLOS ONE 12: e0188486. https://doi.org/10.1371/journal.pone.0188486.

LANDFIRE. 2010. Existing vegetation type layer, forest canopy cover layer, and digital elevation model layer. U.S. Department of the Interior, Geological Survey. https://landfire.cr.usgs.gov/viewer/. Accessed 24 Apr 2019.

LANDFIRE. 2014. Existing vegetation type layer, forest canopy cover layer, and digital elevation model layer. U.S. Department of the Interior, Geological Survey. http://landfire.cr.usgs.gov/viewer/. Accessed 24 Apr 2019.

Lee, D.E. 2018. Spotted Owls and forest fire: a systematic review and meta-analysis of the evidence. Ecosphere 9 (7): e02354. https:/doi.org/10.1002/ecs2.2354.

Lee, D.E., and M.L. Bond. 2015. Occupancy of California spotted owl sites following a large fire in the Sierra Nevada, California. Condor 117: 228-236. https://doi.org/10.1650/CONDOR-14-155.1.

Lee, D.E., M.L. Bond, and R.S. Siegel. 2012. Dynamics of California spotted owl breeding-season site occupancy in burned forests. Condor 114: 792-802. https://doi.org/10.1525/cond.2012.110147.

Levin, S.A. 1992. The problem of pattern and scale in ecology. Ecology 73 (6): 1943-1967. https://doi.org/10.2307/1941447.

Littell, J.S., D. McKenzie, D.L. Peterson, and A.L. Westerling. 2009. Climate and wildfire area burned in western U.S. ecoprovinces, 1916-2003. Ecological Applications 19 (4): 1003-1021. https://doi.org/10.1890/07-1183.1.

Littell, J.S., D. McKenzie, H.Y. Wan, and S.A. Cushman. 2018. Climate change and future wildfire in the western United States: an ecological approach to nonstationarity. Earth's Future 6 (8): 1097-1111. https://doi.org/10.1029/2018EF000878.

May, C.A., M.L. Petersburg, and R.J. Gutiérrez. 2004. Mexican spotted owl nestand roost-site habitat in northern Arizona. Journal of Wildlife Management 68: 1054-1064. https://doi.org/10.2193/0022-541X(2004)068[1054:MSONAR]2.0.CO;2. 
McGarigal, K., H.Y. Wan, K.A. Zeller, B.C. Timm, and S.A. Cushman. 2016. Multi-scale habitat selection modeling: a review and outlook. Landscape Ecology 31 (6): 1161-1175. https://doi.org/10.1007/s10980-016-0374-x.

McKenzie, D., Z. Gedalof, D.L. Peterson, and P. Mote. 2004. Climatic change, wildfire, and conservation. Conservation Biology 18 (4): 890-902. https://doi. org/10.1111/j.1523-1739.2004.00492.x.

Miller, J.D., and H. Safford. 2012. Trends in wildfire severity: 1984 to 2010 in the Sierra Nevada, Modoc Plateau, and southern Cascades, California, USA. Fire Ecology 8 (3): 41-57. https://doi.org/10.4996/fireecology.0803041.

Miller, J.D., E.E. Knapp, C.H. Key, C.N. Skinner, C.J. Isbell, R.M. Creasy, and J.W. Sherlock. 2009a. Calibration and validation of the relative differenced Normalized Burn Ratio (RdNBR) to three measures of fire severity in the Sierra Nevada and Klamath Mountains, California, USA. Remote Sensing of Environment 113 (3): 645-656. https://doi.org/10.1016/j.rse.2008.11.009.

Miller, J.D., H.D. Safford, M. Crimmins, and A.E. Thode. 2009b. Quantitative evidence for increasing forest fire severity in the Sierra Nevada and southern Cascade Mountains, California and Nevada, USA. Ecosystems 12 (1): 16-32. https://doi.org/10.1007/s10021-008-9201-9.

O'Connor, C.D., D.A. Falk, A.M. Lynch, and T.W. Swetnam. 2014. Fire severity, size, and climate associations diverge from historical precedent along an ecological gradient in the Pinaleño Mountains, Arizona, USA. Forest Ecology and Management 329: 264-278. https://doi.org/10.1016/j.foreco.2014.06.032

Odion, D.C., and C.T. Hanson. 2006. Fire severity in conifer forests of the Sierra Nevada, California. Ecosystems 9: 1177-1189. https://doi.org/10.1007/s10021-003-0134-z.

PRISM Climate Group. 2014. Oregon State University. http://prism.oregonstate.edu

Reilly, M.., C.J. Dunn, G.W. Meigs, T.A. Spies, R.E. Kennedy, J.D. Bailey, and K. Briggs. 2017. Contemporary patterns of fire extent and severity in forests of the Pacific Northwest, USA (1985-2010). Ecosphere 8 (3): e01695. https:/doi.org/10.1002/ecs2.1695.

Roberts, S.L., J.W. van Wagtendonk, A.K. Miles, and D.A. Kelt. 2011. Effects of fire on spotted owl site occupancy in a late successional forest. Biological Conservation 144: 610-619. https://doi.org/10.1016/j.biocon.2010.11.002.

Roberts, S.L., D.A. Kelt, J.W. van Wagtendonk, A.K. Miles, and M.D. Meyer. 2015. Effects of fire on small mammal communities in frequent-fire forests in California. Journal of Mammalogy 96: 107-119. https://doi.org/10.1093/ jmammal/gyu011.

Roccaforte, J.P., D.W. Huffman, P.Z. Fulé, W.W. Covington, W.W. Chancellor, M.T. Stoddard, and J.E. Crouse. 2015. Forest structure and fuels dynamics following ponderosa pine restoration treatments, White Mountains, Arizona, USA. Forest Ecology and Management 337: 174-185. https://doi.org/10.1016/j. foreco.2014.11.001.

Rockweit, J.T., A.B. Franklin, and P.C. Carlson. 2017. Differential impacts of wildfire on the population dynamics of an old-forest species. Ecology 98 (6): 1574-1582. https://doi.org/10.1002/ecy.1805.

Sackett, S.S., and S.M. Haase. 1996. Fuel loadings in southwestern ecosystems of the United States. In Proceedings of the Symposium on Fire on Madrean Province Ecosystems, 187-192. Fort Collins: USDA Forest Service General Technical Report RM-GTR-289.

Schoennagel, T., J.K. Balch, H. Brenkert-Smith, P.E. Dennison, B.J. Harvey, M.A. Krawchuk, N. Mietkiewicz, P. Morgan, M.A. Moritz, R. Rasker, M.G. Turner, and C. Whitlock. 2017. Adapt to more wildfire in western North American forests as climate changes. Proceedings National Academy of Sciences 114 (18): 45824590. https://doi.org/10.1073/pnas.1617464114.

Schooley, R.L. 1994. Annual variation in habitat selection: patterns concealed by pooled data. Journal of Wildlife Management 58 (2): 367-374. https://doi.org/ $10.2307 / 3809404$

Seamans, M.E., and R.J. Gutiérrez. 1995. Breeding habitat ecology of the Mexican spotted owl in the Tularosa Mountains, New Mexico. Condor 97: 944-952. https://doi.org/10.2307/1369533.

Shirk, A.J., M.G. Raphael, and S.A. Cushman. 2014. Spatiotemporal variation in resource selection: insights from the American marten (Martes americana). Ecological Applications 24: 1434-1444. https://doi.org/10.1890/13-1510.1.

Singleton, M.P., A.E. Thode, A.J. Sánchez-Meador, and J.M. Iniguez. 2019. Increasing trends in high-severity fire in the southwestern USA from 1984 to 2015. Forest Ecology and Management 433: 709-719. https://doi.org/10.1016/j. foreco.2018.11.039.

Soverel, N.O., D.D.B. Perrakis, and N.C. Coops. 2010. Estimating burn severity from Landsat dNBR and RdNBR indices across western Canada. Remote Sensing of Environment 114 (9): 1896-1909. https://doi.org/10.1016/j.rse.2010.03.013.

Stephens, S.L., N. Burrows, A. Buyantuyev, R.W. Gray, R.E. Keane, R. Kubian, S. Liu, F. Seijo, L. Shu, K.G. Tolhurst, and J.W. van Wagtendonk. 2014. Temperate and boreal forest mega-fires: characteristics and challenges. Frontiers in Ecology and the Environment 12: 115-122. https://doi.org/10.1890/120332.

Stephens, S.L., J.D. Miller, B.M. Collins, M.P. North, J.J. Keane, and S.L. Roberts. 2016. Wildfire impacts on California spotted owl nesting habitat in the Sierra Nevada. Ecosphere 7 (11): e01478. https://doi.org/10.1002/ecs2.1478.

Stine, P.A., and P.N. Manley. 2017. Chapter1: Introduction. In General Technical Report PSW-GTR-254, 1-10. Albany: Pacific Southwest Research Station, Forest Service, U.S. Department of Agriculture.

Thompson, C.M., and K. McGarigal. 2002. The influence of research scale on bald eagle habitat selection along the lower Hudson River, New York (USA). Landscape Ecology 17: 569-586. https://doi.org/10.1023/A: 1021501231182.

Timm, B.C., K. McGarigal, S.A. Cushman, and J.L. Ganey. 2016. Multi-scale Mexican spotted owl (Strix occidentalis lucida) nest/roost habitat selection in Arizona and a comparison with single-scale modeling results. Landscape Ecology 31: 1209-1225. https://doi.org/10.1007/s10980-016-0371-0.

U.S. Department of Agriculture. 2004. Hayman fire and BAER information. https:// www.fs.usda.gov/detail/psicc/home/?cid=fsm9_032493. Accessed 15 Mar 2018.

U.S. Department of Agriculture. 2012. Whitewater baldy complex burned area emergency response (BAER) team executive summary. https://www.fs.usda. gov/Internet/FSE_DOCUMENTS/stelprdb5375619.pdf. Accessed 15 Mar 2018.

U.S. Department of Agriculture. 2014. Wallow Fire case study suggests there may be multiple paths to fuel reduction in the wildland-urban interface. https://www.fs.fed.us/outernet/pnw/news/2014/05/wallow-fire.shtml. Accessed 25 Oct 2019

U.S. Department of Agriculture. 2019. Forest Activity Tracking System (FACTS), Southwestern Region (Region 3) GIS Data, U.S. Forest Service. https://www.fS. usda.gov/detailfull/r3/landmanagement/gis/?cid=stelprdb5201889\&width=full. Accessed 31 Oct 2019.

U.S. Department of Interior. 2012. Final Recovery Plan for the Mexican Spotted Owl (Strix occidentalis lucida), First Revision. Albuquerque: U.S. Fish and Wildlife Service.

U.S. Geological Survey. 2017. Monitoring Trends in Burn Severity. http://www. mtbs.gov Accessed 15 Mar 2018.

Waltz, A.E.M., M.T. Stoddard, E.L. Kalies, J.D. Springer, D.W. Huffman, and A. Sánchez Meador. 2014. Effectiveness of fuel reduction treatments: assessing metrics of forest resiliency and wildfire severity after the Wallow Fire, AZ. Forest Ecology and Management 334: 43-52. https://doi.org/10.1016/j.foreco. 2014.08.026.

Wan, H.Y., K. McGarigal, J.L. Ganey, V. Lauret, B.C. Timm, and S.A. Cushman. 2017. Meta-replication reveals nonstationarity in multi-scale habitat selection of Mexican spotted owl. Condor 119 (4): 641-658. https://doi.org/10.1650/ CONDOR-17-32.1.

Wan, H.Y. 2018. Habitat, connectivity, and gene flow of Mexican spotted owl under altered fire regimes in southwestern forests. Northern Arizona University, ProQuest Dissertations Publishing 10787813. https://search. proquest.com/openview/388f42fe39f0a4c582008eea4c73e4ae.

Wan, H.Y., S.A. Cushman, and J.L. Ganey. 2018a. Habitat fragmentation reduces genetic diversity and connectivity of the Mexican spotted owl: a simulation study using empirical resistance models. Genes 9 (8): 403. https://doi.org/10. 3390/genes9080403.

Wan, H.Y., J.L. Ganey, C.D. Vojta, and S.A. Cushman. 2018b. Managing emerging threats to spotted owls. Journal of Wildlife Management 82 (4): 682-697. https://doi.org/10.1002/jwmg.21423.

Wan, H.Y., S.A. Cushman, and J.L. Ganey. 2019a. Improving habitat and connectivity model predictions with multi-scale resource selection functions from two geographic areas. Landscape Ecology 34 (3): 503-519. https://doi. org/10.1007/s10980-019-00788-w.

Wan, H.Y., S.A. Cushman, and J.L. Ganey. 2019b. Recent and projected future wildfire trends across the ranges of three spotted owl subspecies under climate change. Frontiers in Ecology and Evolution 7: 37. https://doi.org/10. 3389/fevo.2019.00037.

Westerling, A.L., H.G. Hidalgo, D.R. Cayan, and T.W. Swetnam. 2006. Warming and earlier spring increase western U.S. forest wildfire activity. Science 313 (5789): 940-943. https://doi.org/10.1126/science.1128834.

Wheatley, M., and C. Johnson. 2009. Factors limiting our understanding of ecological scale. Ecol. Complex. 6: 151-159. https://doi.org/10.1016/j.ecocom. 2008.10.011.

Wiens, J. 1989. Spatial scaling in ecology. Functional Ecology 3: 385-397. https:// doi.org/10.2307/2389612. 
Willey, D.W., and C. van Riper III. 2007. Home range characteristics of Mexican spotted owls in the canyonlands of Utah. Journal of Raptor Research 41: 10-15. https://doi.org/10.3356/0892-1016(2007)41 [10:HRCOMS]2.0.CO;2.

Williams, J. 2013. Exploring the onset of high-impact mega-fires through a forest land management prism. Forest Ecology and Management 294: 4-10. https://doi.org/10.1016/j.foreco.2012.06.030.

Williams, M.A., and W.L. Baker. 2012. Spatially extensive reconstructions show variable-severity fire and heterogeneous structure in historical western United States dry forests. Global Ecology and Biogeography 21: 1042-1052. https://doi.org/10.1111/j.1466-8238.2011.00750.x.

Ziegler, J.P., C. Hoffman, M. Battaglia, and W. Mell. 2017. Spatially explicit measurements of forest structure and fire behavior following restoration treatments in dry forests. Forest Ecology and Management 386: 1-12. https://doi.org/10.1016/j.foreco.2016.12.002.

\section{Publisher's Note}

Springer Nature remains neutral with regard to jurisdictional claims in published maps and institutional affiliations.

\section{Submit your manuscript to a SpringerOpen ${ }^{\circ}$ journal and benefit from:}

- Convenient online submission

- Rigorous peer review

- Open access: articles freely available online

- High visibility within the field

- Retaining the copyright to your article

Submit your next manuscript at $\boldsymbol{\nabla}$ springeropen.com 